\author{
(online) $=$ ISSN $2285-3642$ \\ ISSN-L = 2285 - 3642 \\ Journal of Economic Development, Environment and People \\ Volume 2, Issue 4, 2013 \\ URL: http://jedep.spiruharet.ro \\ e-mail: office jedep@spiruharet.ro
}

\title{
Values as Motivation Factors of Economic Behaviour
}

\author{
Ing. Martin Lačný, PhD. ${ }^{1 \text { 回 }}$ \\ ${ }^{1}$ University of Prešov, Slovakia
}

\begin{abstract}
.
The article presents a reflection on the structure of values functioning as motivators of economic behaviour. Considering the principle of rational egoism the author describes three segments of crucial values, which seem to be fundamental, as a matter of the contemporary Euro-American economic value system - freedom and justice; responsibility and confidence; progress, prosperity and rationality. An important methodological basis of presented reflection is the Ethics of social consequences - dynamically developing consequentialist ethical theory, responding to the challenges arising in the field of applied ethics in the framework of efforts to solve practical problems of today's world.
\end{abstract}

Keywords: values, economic behaviour, freedom, justice, responsibility, confidence, progress, prosperity, rationality

JEL Codes: A13, D03, M14, Z13

\section{Introduction}

When mapping dispersed and some what internally contradictory realm of values, we are confronted with the psychologically important fact tha values act as important motivational variables. In relation to human behaviour they act in relation to reflexes, instincts, archetypal influences, tendencies, needs, motives, desires, wishes, interests, goals, aspirations and ideals. This richset of motivational factors thus includes variables with a predominance of biological determination, together with the socio-culturally based motivational variables that affect the interaction of values, which may exhibit varying degrees of conscious, respectively subconscious influence (Putnová and Seknička, 2007, p. 60-63).

When evaluating and shaping the value orientation, as well as in case of the evaluation of economic categories, comes to the fore the fact that values are associated with human needs and interests. The needs quite clearly constitute a project basis of our activities and therefore of ten equate with value orientations, or in subjectivist interpretations even with values. They are being perceived mostly through culturally stabilized, institutionalized ways of satisfaction. Human societies vary in a manner of institutionalized ways of satisfaction, as well as in ways of institutionalization of value systems.

\footnotetext{
${ }^{+}$Corresponding author - Tel.: + 421 (0)51 7724380 E-mail address: martin.lacny@unipo.sk
} 


\author{
(online) $=$ ISSN $2285-3642$ \\ ISSN-L = $2285-3642$ \\ Journal of Economic Development, Environment and People \\ Volume 2, Issue 4, 2013 \\ URL: $\underline{\text { http://jedep.spiruharet.ro }}$ \\ e-mail: office jedep@spiruharet.ro
}

Current form ofthe application of values in the economic sphere, as stated by several renowned authors, is in our civilization context basedon Euro-American value system for economic practice. Within this system there are incorporated primarily values as freedom, justice, responsibility, confidence, progress, prosperity, rationality. These basal values we can split into three segments in order to get a clear picture of the values in the context of our economic behaviour (Putnová and Seknička, 2007, p. 51-52). Consequently, in our text we will try to confront this value framework with the core value structure of the Ethics of social consequences and other concepts of ethical thinking. It is quite important to note that the concept of the Ethics of social consequences, as well as other forms non-utilitarian consequentialism, enter in to the outlined discourse as an attempt to bring new solutions to the traditional questions of consequentialist ethics, which utilitarianism cannot reliably answer (Gluchman, 1995, p. 108).

\title{
2. First segment-freedom and justice
}

The first segment is characterized by values of freedom and justice, which co-create a democratic society, open for business and the realization ofeconomic activities. These values are understood as the basis of legality and legitimacy of human action, while inp ractice the need to ensure a harmonious, balanced relationship of freedom and justice is being emphasized.

Freedom is a core value of practical human activities, in the most general sense it refers toone's ability to self-determine his actions and deeds, to act according to his own reasoning, based on his own decisions. Human creativity involves the ability to imagine, think through and implement something new. Michael Novak notes in this context that the Smithian question, what is the cause of the wealth of nations, can be answered very simply: intellect, ingenuity, inventiveness and human creativity. Human personality is the source of inventiveness, entrepreneurship and economic dynamics. Almost all the everyday little things that make our life more enjoyable are the fruits of economic creativity (Novak, 1996, p. 42-43). In the aforementioned "creative personality" of man we find the principle of freedom that naturally develops itself in conscience, investigations and actions, whilst creativity is a higher category than freedom. Creativity is bound to be free, but freedom must be subordinated to something else.

In the context of the Ethics of social consequences are creativity and productivity deducted from humanity, understood in terms of protection, support and development of human life, while the key moment here is the focus on human life. Positive social consequences, if they are achieved in accordance with the principles of humanity, law andjustice, then create good, which is a prerequisite for the development of man'screative powers.

This important role of creativity of a moral entity is related to the realization of dynamic stability as a prerequisite for the implementation of the successive steps leading to moral self-improvementas well as to moral development of mankind (Gluchman, 1999, p. 30-32). 


\author{
(online) $=$ ISSN $2285-3642$ \\ ISSN-L = $2285-3642$ \\ Journal of Economic Development, Environment and People \\ Volume 2, Issue 4, 2013 \\ URL: $\underline{\text { http://jedep.spiruharet.ro }}$ \\ e-mail: office jedep@spiruharet.ro
}

The dynamics o any economic system is thus essentially determined by the moral habits of citizens. Economic activities have their originin human freedom, which is understood as a moral dimension. Passive population, not benefiting from freedom, achieves in comparison with more enterprising population substantially lower range of economic activities. Moreover, virtues and the vices, characterizing population, define the profile of the economic constraints. History shows that the use of freedom affects not only the internal moral form of economic activity, but also economic results (Novak, 1996, p. 41).

Human activity always involves a moment of freedom and coercion, the only problemis whether in case of particular activity the degree of freedom prevails over degree of external compulsion. The freedom of choice comes along in the process of human activity (specifically in determining the objectives, the means by which we want to achieve the objective). However, the choice itself is only an objective precondition of freedom of man. The real human freedom begins in the subjective use of this objective possibility. Freedom of mandoes not consist only in understanding the necessity, because if one understands the necessity, emancipates only in the spiritual level (but not in the economic and socio-political level).

An economic subject may develop its individual freedom - to be creative, original and imaginative in economic activity, to acquire customers, traders, buyers, consumers in different ways, to conduct business meetings and relationships in various ways, which will distinguish him from the competition. But in the implementation of its business strategy and its objectives, the expression of individual freedom will end where the protected area of others begins (in the sense of negative expression of freedom). At the same time the freedom of action of an economic subject is limited not only by other entities, but also and in particular by legislation applicable for business.

Economic freedom an be characterized as well as the absence of government coercion or restriction of production, distribution and consumption of goods and services whose cope goes beyond what is necessary to protect and maintain the freedom of citizens. In other words, peopleare free to work, produce, consume and invest in ways that they believe are most productive. Any action of government includes coercion. If the state intervenes in the market environmentat a rate exceeding the protection of individuals and property, this intervention undermines economic freedom. Not only through the Public choice theory we know that if bureaucratic power restricts people, their behaviou changes for the worse. The degree of economic freedom is being reduced-and so are the prosperity and the level of economic activity.

Justice as avalue is associated with equality of general rules given by law and the general rules of conduct. In general, it is understood as equality, but not egalitarianism, which is inherently unfair. Between freedom and equality, there is often a contradiction, which comprises the development of personal freedom, mostly generating inequality. Promoting justice, however, often does not result in removal of material inequality, buton the contrary. Justiceis being in the commutative and distributive sense regarded as something that somehow restores balance and proportion. 


\author{
(online) = ISSN $2285-3642$ \\ ISSN-L = 2285-3642 \\ Journal of Economic Development, Environment and People \\ Volume 2, Issue 4, 2013 \\ URL: $\underline{\text { http://jedep.spiruharet.ro }}$ \\ e-mail: office jedep@spiruharet.ro
}

According to John Rawls, accentuating a macro-societal level, justiceis the framework of a democratic society. As the primary subject of political justice is yet considered the basic structure of society, namely the main political and social institutions and how they fit into each other, forming a unified system of cooperation. Rawls in his view on justice as fairness states that everyone has the unquestionable right to quite adequate scheme of equal basic liberties, while this scheme is compatible with the same scheme of liberties for all. Social and economic in equality would thus have to fulfil two conditions. They should be confined to offices and positions accessible for all underconditions offaire quality of opportunities and at the same time they should be as much as possible for the benefit of the least advantaged members of society (Rawls, 2007, p. 73-91).

While this often cited concept of justice means the realization of the principle of justice from above, the Ethics of social consequences emphasizes the micro-societal level, thus the implementation of the principle of justice from below - at the level of individual life of a moral entity, while trying to solve for example also issues related to interpersonal relations beyond the scope of the organization of a society (Gluchman, 1999, p. 33). Ethics of social consequences perceives justice as a prerequisite for the acceptance of individual freedom, which is conditional to the equality rights, as a provision of a moral right to a dignified life (including its economic and social aspects expressed in the form of legal rights), performed through the implementation of humanity and human dignity (this definition of justice is valid also on the macro-societal level). Any humane behaviour of a moral entity in order to achieve only the positive social consequences (or their predominance over the negative social consequences) is seen as fair (correct, moral and therefore praiseworthy). Any intentional behaviour of a moral entity, supporting in human econduct is unfair and therefore reprehensible. Proceedings leading to negative social consequences that occurunder the influence of external factors, which cannot be affected by acting entity are assessed as non-fair, incorrect as a matter of consequences, but not reprehensible in relation to the motives. Thus, if a moral entity acts freely, exercises its rights and at the same time does not harm, does not endanger, does not interfere with the rights of others in recognition of their dignity -then it acts justly, rightly, respectively morally and praiseworthy. Implementatio nof freedom and rights, bringing positive social consequences, is a precondition for justice - on the otherhand, their suppression is unfair (Platková Olejárová, 2011, p. 65-76).

Positive social consequences create conditions for the development of creative powers and abilities of man, as well as for the development of the creative potential of the community. However, this role may be filled by them only when resulting from fair decisions and actions - that means when they comply with humanity and legality. Justice in the Ethics of social consequences is thus a defining moment of goodness-a concrete assessment of humanity and legality of decisions and actions of a moral entity (Gluchman, 1999, p. 18-19).

Gary S. Becker points out in his Economic theory of discrimination on the key role of non-market factors (exclusion, barriers to education, caste systems, etc.) for maintaining a supportive environment for injustice 


\author{
(online) $=$ ISSN $2285-3642$ \\ ISSN-L = $2285-3642$ \\ Journal of Economic Development, Environment and People \\ Volume 2, Issue 4, 2013 \\ URL: $\underline{\text { http://jedep.spiruharet.ro }}$ \\ e-mail: office jedep@spiruharet.ro
}

and discrimination. Discriminationis from the perspective of this concept particularly harmful if it in certain groups suppresses stimuli to work and to invest in human capital. This happens in case of statistical discrimination when the approach to certain individuals is based on the average behaviour of members of the group to which they belong. An example would be the stereotypicalas sessment of employees by the employer according to their nationality, race, gender, but also for example depending on the college which they graduated from. This form of discrimination creates a stereotypical view of an individual based on group characteristics, reduces the incentives for self-improvement, which leads to re-strengthening of the original stereotype (Samuelson and Nordhaus, 2000, p. 252-253).

While older approaches, dealing with the elimination of injustice and discriminatory practices, stressed the elimination of unjust legal decisions and actions, respectively unfair treatment of individuals in the group processes, newer approaches favour particular requirements for the implementation of positive motivationin this respect.

\title{
3. Second segment -responsibility and confidence
}

The second segment of this value system includes values, without which the economy based on market principles could not work-responsibility and confidence. Both mentioned values are the foundation of all contractual relations and create conditions for fair competition, which is one of the essential components of market mechanism. They play an important role also in the construction of relational frameworks invarious legal forms of business, especially in case of companies operating on the basis of separated owner ship and management.

Responsibility as an ethical value has a very close relationship to freedom as the most important value of human experience. Legal, political and moral responsibility largely affects the daily decision-making, as well as human behaviour. Under conditions of market economy the voluntary economic transactions between market actors represent a large part of economic life. It is quite clear that freedom without responsibility increases the societal transaction costs, which can result in the form of negative externalities and overall inefficiency of the economic system.

The principle of responsibility is closely connected with the principle of justice, which actually determines the content of the responsibility principle. Moral responsibility is generally associated with the implementation of the principle of justice - that means with a conduct, which respects and affirms the fundamental moral values existing in human society. This regards particularly the ability of awareness of responsibility, calculating with this responsibility in the process of moral reasoning, or decision-making and subsequent proceedings in accordance with the awareness of responsibility.

Hans Jonasas signs another importantat tribute to responsibility, when he talks about it as about the correlate of power. The extent and type of power thus determines the extent and type of responsibility that comes with it. If power reaches certain dimensions, it changes not only in volume but also as a matter 


\author{
(online) = ISSN $2285-3642$ \\ ISSN-L = 2285-3642 \\ Journal of Economic Development, Environment and People \\ Volume 2, Issue 4, 2013 \\ URL: $\underline{\text { http://jedep.spiruharet.ro }}$ \\ e-mail: office jedep@spiruharet.ro
}

of quantitative nature of responsibility, so that actions of power create the content of obligation, which inherently becomes a response to what happened (Jonas, 1997, p. 190-191).

As a matter of determination of the subject of responsibility, there is no unity of opinion among the theoretical concepts dealing with the issue of responsibility in economic context. Within the development of views on responsibility in business we register two basic lines, respectively, two main optical modesStockholders theory and Stakeholders theory.

Milton Friedmanas the representative of the first of these concepts is of the opinion that the only social responsibility of business is efficient use of scarce resources and activities leading to increased profit of owners, while respecting the rules of the game established by the legal framework (Friedman, 1970). This approach to social responsibility in business is based on an assumption that competition removes from the market the undesirable forms of behaviour damaging market participants and the market itself. Since this approach concentrates on responsibility to owners (or shareholders generally) of enterprises, in the literature it is usually indicated by its name Stockholders theory.

Friedman has built his call into question of a broader corporate responsibility on several arguments. Enterprise as a legal person is understood by him as a social construct - artificial unit, while responsibility can be held only by a real person (e.g. entrepreneur or manager of corporation). Management of enterprise according to M. Friedman is a deputy of owners and its primary obligation is the responsibility to owners, not to a wider range of interest groups. The consideration and protection of non-shareholders interest groups would be practically happening at the expense of shareholders, who would have been then practically taxed by management (which is not within its remit). Stockholders theory thus encourages individual responsibility, because according to its arguments the idea of a broader concept of corporate social responsibility reduces economic freedom (thus damages the freedom of society) when the enterprise itself makes commitments which deforma pluralistic confrontation of interests (Putnová and Seknička, 2007, p. 128).

In the context of corporate social responsibility, conceived along the lines of Stakeholders theory, we understand the responsibility as principal relation of business to legal, respectively moral obligations imposed by law, contract, or other moral and social conventions and norms. The classification of corporate social responsibility is yet built on three pillars-economic, social and environmental. The very concept of stakeholder is within Stakeholders theory defined as a group, without support of which the organization could not exist. This term thus describes the relationship of business entity to internal and external social groups that are affected by the activities of organization, and which at the same time affect by their activities the operation of the organization. This includes owners (respectively shareholders), employees, managers, customers (respectively consumers), suppliers, creditors, competitors, government (respectively state authorities), regions, society. The enterpriseis understood here as a subject of responsibility-as a separate entity, which is responsible to particular stakeholders (participating groups) for real and for 


\author{
(online) $=$ ISSN $2285-3642$ \\ ISSN-L = $2285-3642$ \\ Journal of Economic Development, Environment and People \\ Volume 2, Issue 4, 2013 \\ URL: $\underline{\text { http://jedep.spiruharet.ro }}$ \\ e-mail: office jedep@spiruharet.ro
}

eseeable consequences of its actions. The purpose of business according to Stakeholders theory should therefore be to serve the interests of stakeholders.

Although the moral responsibility of any organization can not be clearly severable from its social responsibility, we can conclude that where as in case of corporate social responsibility we are stressing the role of a company in terms of its position and function in society, in case of moral responsibility it comes to consideration of the effects of its actions from the perspective of justice and fair treatment of all stakeholders. The central issue here is not just a question of participation on development of the whole society, the discourse is shifted exclusively to the sphere of moral values. The concept of responsibility relates here to moralliability for the acts and their consequences, as well as to the obligation of exposure to an informal positive or negative assessment of these acts. Approvingly with the concept of the Ethics of social consequences, we can conclude that expansion of the scale and scope of responsibility is now primarily based on rational egoism of man and mankind in general, which is to some extent influenced and strengthened also by a feeling offear. Compassion, mercy or charity, do not fulfil this role. Ethics of social consequences considers important to define the role of individuals in decision-making and action and subsequently on that basis to define the degree of moral responsibility for the activities of social groups (Gluchman, 2005, p. 23).

Hans Jonas emphasizes principally the future-oriented nature of responsibility. Human responsibility, which refers to mankind and nature, is in his opinion total, continuous and future-oriented. The future of nature and human society therefore constitutes an own future-oriented aspect of responsibility, while the whole scope of responsibility must be grasped in its historicity (Jonas, 1997, p. 37-42). Jonas'principle of responsibility is focused on the future (a prospective responsibility), while responsibility for the present andretrospective responsibility are getting into the background. Similar moments are present even in utilitarian concepts, for which the past is few interesting - decisive is the future. However, the responsibility for implementing the rights and dignity of manis directed primarily to the presence, while it necessarily includes the dimension of responsibility in relation to the future. Jonas'concept of responsibility thus accentuates mainly macro-societal dimension, which does not create enough space for the realization of responsibilityin everyday life of an individual or social community (Gluchman, 1999, p. 32-33).

From the perspective of the Ethics of social consequences, the obligation to present is over riding and the obligation to the future must be taken into account to not rule out its implementation. Int his context, the Ethics of social consequences speaks not about moral responsibility for the actions, but about moral responsibility fort he consequences that these actions will bring (Gluchman, 2005, p. 121).

Responsibility is closely linked with confidence, which can be understood as the degree of positive attitude of someone who believes in good faith and reliability of someone to whom he believes - even in risky and changing situations. Through confidence are the involved parties determined to continue with relationship as long as the counterparty behaves appropriately. This confidence is yet based on knowledge, 


\author{
(online) $=$ ISSN $2285-3642$ \\ ISSN-L = $2285-3642$ \\ Journal of Economic Development, Environment and People \\ Volume 2, Issue 4, 2013 \\ URL: $\underline{\text { http://jedep.spiruharet.ro }}$ \\ e-mail: office jedep@spiruharet.ro
}

experience and expectations. Without responsibility and confidence would not be possible to enter into contractual relations, to implement any consensus, based on conditional trust and accountability of involved parties (Putnová and Seknička, 2007, p. 58).

For example, relations of an organization and stakeholders (or interest groups) usually acquire the nature of legal or social contract, which includes a description of eventual sanctions fornon-compliance with contract terms. Any treaty, however, fails to capture and encompass the entire breadth and complexity of social relations. Reliability and trust, responsible approach to partners, correct conduct, an ability to not misuse current capabilities of a partner and like wise, are such phenomena that can not be decreed, or ordered. Conduct based on universal principles of morality is a matter being drawn upover the years by small, in terms of morality honest steps (Remišová, 2004, p. 60).

Modern theory of management, having its praxeological character, accentuates involvement (commitment) of employees in corporate activities, which presupposes their voluntary identification with the company, its goals and objectives. The key element, determining nature and quality of interpersonal relationships in the workplace and employee-employer relations, is from this point of view just confidence. Creating an atmosphere of confidence, particularly important in terms of motivating employees and managers means to ensure transparency and to strive for fair solutions of particular (not only) conflict situations.

\title{
4. Third segment - progress, prosperity and rationality
}

The third segment contains values the importance of which is associated with the dynamics of growth and economic development-progress, prosperity and rationality. In the context of the Ethics of social consequences we can consider them as values whose mission is to contribute to the realization of moral goodness. If humanity is understood as the behaviour and actions, leading to the protection and promotion, i.e. development of human life, the role of progress, prosperity and rationality will be closely linked to the performance of active humanity in order to achieve positive social consequences.

Progress is the fundamental value for economic growth and development at the macroeconomic and microeconomic level. Contemporary economy is in terms of its dynamics based on the creative process of entrepreneurial discovering, innovating and realization of new opportunities, replacing less productive activities by more efficient ones -the process that is driven by competition. Progress as a value is in the logic of this system as sociated with economic prosperity, expressing its relationship to economic success and general usefulness.

With a systematic definition of the content of category of progress we have been confronted in the works of Joseph Alois Schumpeter, whoin his Theory of economic development distinguished between static economic growth and dynamic economic development. Dynamic development is according to him caused by innovations, the bearer of which is an entrepreneur. Static economic growth, according to 


\author{
(online) $=$ ISSN $2285-3642$ \\ ISSN-L = $2285-3642$ \\ Journal of Economic Development, Environment and People \\ Volume 2, Issue 4, 2013 \\ URL: http://jedep.spiruharet.ro \\ e-mail: office jedep@spiruharet.ro
}

Schumpeter means only constant repetition of the same variables in production, as well as in consumption. Constantly repeated combinations of production factors at constant consumer preferences lead to a"steady state" which is characterized as quantitative economic growth. Development process, according to Schumpeter begins only when this steady state is disturbed by changes: "to produce means to combine things and forces that are within our reach - the form and content of development in our understanding are then given by aconcept: the enforcement of new combinations" (Schumpeter, 1987, p. 196-197). The market mechanism ensures that in a competitive environment new combinations are being implemented, while less efficient combinations are being eliminated and factors of production are with drawn to other usage. In the Schumpeterian sense then also the concept of market competition acquires new content. It is not understood as acompetition between the companies that are involved insteady economic growth, thus acompetition between identical goods, they manufacture. It is acompetition between innovated and original goods, the innovated and original production methods. It is therefore a distortion of stationary growth within the meaning of "the process of creative destruction." Innovations are therefore a content of changes that disturb the stationary steady economic growth and cause a dynamic economic development.

Economists are agreed that in the last decade of $20^{\text {th }}$ century occurred in the economies of developed countries changes, the importance of which is often compared to the industrial revolution. These changes are associated with new technologies, whose impact on the reproductive process and economy is so significant that economic theory begins to assign to the classical production factors - labour, capital, land and natural resources also knowledge and innovations as a specific production factor. The impact of new technologies on the economy and the associated processes are considered as factors underlying the transition of economies to a new quality, in literature known as "new economy", "knowledge society," "information society," "knowledge economy," or "digital economy" (Lisý et al., 2005, p. 58).

In current conditions of new economy, accentuating the knowledge dimension of economic activities, prosperity is closely linked with rationality as the value of fundamental importance (Putnová and Seknička, 2007, p. 51-59). One of the first reactions within the economic thinking to the new effects of technological changes on the conduct of economic entities, functioning of markets and society as a whole, has been the Theory of rational expectations (Robert Lucas, Thomas Sargent, Robert Barro), which was formed already in the 1970s. It was the technological progress and the development of information technologies, which significantly reduced the time required for the exchange of information, and reduced the costs associated with their exchange and evaluation, and therefore made the main as sumption of rational expectations theorists more realistic - as according to them the economic a gents form their expectations rationally, evaluate all available information systematically and build them into their expectations about the future (Lisý et al., 2005, p. 59).

In the context of current economic and social realia, we can conclude that the above mentioned value segments currently determine majoritarian economic behaviour, as well as the development of economic systems and economic thinking primarily within Western civilization. Globally, it is important to note that 


\author{
(online) $=$ ISSN $2285-3642$ \\ ISSN-L = $2285-3642$ \\ Journal of Economic Development, Environment and People \\ Volume 2, Issue 4, 2013 \\ URL: $\underline{\text { http://jedep.spiruharet.ro }}$ \\ e-mail: office jedep@spiruharet.ro
}

this setting of value framework affects the value fundaments of economic systems outside of our civilizational context, but it is also being under influence of alternative value orientations, having their source in the context of different cultures. Thanks to acculturation processes, accelerated by globalization and interdependence of economies, innovations of the mentioned Euro-American system of values for economic practices are continuously going on, causing modifications in the details of its specific current forms, respectively its gradual re-composition.

\title{
5. Acknowledgements
}

The study is a partial output of the research project VEGA No. 1/0789/11.

\section{References}

[1] M. Friedman. The Social Responsibility of Business is to Increase its Profits. In: New York Times Magazine, September 13, No. 9/1970.

[2] V. Gluchman. Etika konzekvencializmu. Prešov: ManaCon 1995. 116 p. ISBN 80-85668-18-1.

[3] V. Gluchman. Etika sociálnych dôsledkov v kontextoch jej kritiky. Prešov: L.I.M. 1999. 142 p. ISBN 80-967778-4-X.

[4] V. Gluchman. Človek a morálka. Prešov: L.I.M. 2005. 191 p. ISBN 80-89012-03-5.

[5] H. Jonas. Princip odpovědnosti. Prague: Oikoymenh 1997. 320 p. ISBN 80-86005-06-2.

[6] J. Kalajtzidis. Problematika mravných subjektov v etike sociálnych dôsledkov. In: V. Gluchman, et al. Hodnoty v etike sociálnych dôsledkov. Prešov: Grafotlač 2011. p. 86-122. ISBN 978-80-555-0192-5.

[7] M. Lačný. Spoločenská zodpovednost' podnikov a korporatívne občianstvo - otázky a výzvy. Prešov: Vydavatel'stvo Prešovskej univerzity 2012. 102 p. ISBN 978-80-555-0425-4.

[8] J. Lisý, et al. Ekonómia v novej ekonomike. Bratislava: Iura edition 2005. 624 p. ISBN 80-88715-81-4.

[9] M. Novak. Filozofia slobody. Bratislava: Charis 1996. 172 p. ISBN 80-88743-16-8.

[10] G. Platková Olejárová. Spravodlivost' v etike sociálnych dôsledkov. In: V. Gluchman, et al. Hodnoty v etike sociálnych dôsledkov. Prešov: Grafotlač 2011. p. 65-76. ISBN 978-80-555-0192-5.

[11] A. Putnová, P. Seknička. Etické ř́zení ve firmě. Praha: Grada Publishing 2007. 168 p. ISBN 978-80-247-1621-3.

[12] J. Rawls. Spravodlivost' ako férovost'. Bratislava: Kalligram 2007. 336 p. ISBN 80-7149-911-0.

[13] A. Remišová. Etika a ekonomika. Bratislava: Ekonóm 2004. 238 p. ISBN 80-225-1820-4.

[14] P. A. Samuelson, W. D. Nordhaus. Ekonómia. Bratislava: Elita 2000. 864 p. ISBN 80-8044-059-X.

[15] J. A. Schumpeter. Teória hospodárskeho vývoja. Bratislava: Pravda 1987. 478 p. 